\title{
Ars Historica no Antigo Regime: a História antes da Historiografia
}

\author{
Ars Historica in the Ancient Regime: \\ the History before Historiography
}

\author{
MARCOS ANTÔNIO LOPES \\ Professor na Universidade Estadual de Londrina \\ Doutor em História pela Universidade de São Paulo \\ Depto. de Ciências Sociais \\ Universidade Estadual de Londrina \\ malopes@uel.br/marcos.lopes@pq.cnpq.br
}

RESUMO Ainda que se ocupe em apresentar questões relativas à definição da História como gênero literário e como campo disciplinar, o artigo se empenha em analisar concepções antigas e modernas acerca da História. Passando em revista idéias e gêneros de História surgidos ao longo dos séculos XVI, XVII e XVIII, a análise concentra-se na especulação das vias pelas quais a História transformou-se em agudo instrumento, ora de desconstrução, ora de legitimação de princípios do interesse do Estado régio em meio aos jogos do poder no Antigo Regime.

Palavras-chave Gêneros de História, Pensamento Histórico, Poder Político.

ABSTRACT This article intends to analyze old and modern opinions on History, although it presents issues concerning the definition of History as a literary genre as well as a discipline field. Reviewing ideas and History genres that emerged along the $16^{\text {th }}, 17^{\text {th }}$ and $18^{\text {th }}$ centuries, the analysis focuses on the speculation on ways through which History was transformed into a keen

Artigo recebido em: junho/2008. 
instrument, sometimes of deconstruction, sometimes of legitimating of principles of the sovereign State amid power games in the Ancient Regime.

Keywords History Genres, Historical Thought, Political Power.

Não ornei esta obra e nem a enchi de períodos sonoros ou de palavras empoladas e floreios ou de qualquer outra lisonja ou ornamento extrínseco com que muitos costumam descrever ou ornar as próprias obras; porque não quis que coisa alguma seja seu ornato e a faça agradável senão a variedade da matéria e a gravidade do assunto.

Maquiavel, O Príncipe.

Escolhem-se, geralmente, para historiógrafos - sobretudo em nossa época - indivíduos medíocres, somente porque sabem falar bonito como se fosse para aprender gramática que precisássemos de suas obras. (...) tendo sido escolhidos unicamente por causa de sua tagarelice com isto se preocupam; e, recheadas de belas frases e boatos ouvidos nas praças das cidades, compõem as suas crônicas.

Montaigne, Ensaios.

Mas o abade Dubos abeberou-se em más fontes para um historiador: os poetas e os oradores. Não é sobre obras de ostentação que se devem fundar os sistemas.

Montesquieu, Do Espírito das Leis.

Pensei em compor o título deste artigo sem ambigüidades. Na seqüência da expressão latina Ars Historica - que define um aglomerado de tradições antigas de escrita da História - , figuraria o complemento "Considerações sobre a História da Historiografia". Portanto, o conteúdo ficaria expresso de modo a não deixar margem a dúvidas quanto à natureza do objeto retratado. De imediato, o leitor teria de descobrir apenas quais seriam os gêneros de História estudados num trabalho sobre antigas concepções de História. Mas, em nome de certo rigor no emprego da terminologia, julguei que começar um texto de maneira tão anacrônica não seria bom exercício intelectual, tendo em vista os anacronismos involuntários que certamente hão de se acumular ao longo das análises. Dessa forma, resolvi abolir a expressão "História da Historiografia" para ficar com algo menos impreciso. Com efeito, a "A História antes da Historiografia" apresenta menores riscos de deslizes terminológicos, sem deixar de expressar, de forma pertinente, a natureza da matéria que compõe a reflexão. 
Dito isso, é bom lembrar que, se se fala com freqüência em História da Historiografia, quase sempre é de forma imprecisa e equivocada. Isso porque algumas análises parecem avalizar o argumento de que sempre houve escolas perfeitamente organizadas de pensamento histórico e, dentro destas, autênticas e bem definidas linhas de pesquisa. Ora, se a História é mesmo um antigo "componente" da cultura ocidental, o mesmo não se pode afirmar quanto à Historiografia, que remete a noções bem mais recentes. Autores como J acques Le G off e Peter Burke consideram que se pode falar com propriedade em Historiografia - isto é, em uma "ciência da História" - apenas naquilo que diz respeito a uma forma de saber organizado por determinadas técnicas reconhecidas como aparato metodológico comum a um grupo de especialistas, ou seja, a uma restrita comunidade de profissionais. ${ }^{1}$ Segundo o critério proposto por Thomas Khun, Anthony Giddens observa que um determinado campo de estudo transformar-se-á em ciência somente quando for capaz de adquir um "paradigma". Isso ocorrerá quando existir consenso entre os respectivos investigadores da área acerca das premissas de base e dos métodos de sua atividade. ${ }^{2}$ Essas características apareceram apenas a partir do século XIX. "Os historiadores consideram amiúde o começo do século XIX como o período clássico da sua disciplina", analisa o teórico Hayden White, porque foi nesse perío do que se verificou uma nova concepção da própria história vivida, aliada à percepção das vantagens a se extrair das alianças da História conhecimento com outros campos disciplinares e com a própria cultura. ${ }^{3}$

Mas isso não autoriza falar em termos muito genéricos como, se de um dado momento a outro, passasse a existira, por exemplo, uma "historiografia européia". Várias são as diferenças nacionais que, ainda hoje, distinguem os traços característicos das pesquisas produzidas na Espanha, em Portugal, na Inglaterra, Alemanha ou França. Entretanto, como escrevia J ean Glénisson - em suas lições aos estudantes brasileiros nos anos 1960 -, há muito que se estabelecera na Europa uma "concepção média" do que deveria ser a pesquisa histórica. Esse padrão médio, no dizer de Glénisson, era perceptível por toda parte, o que tornava possível a identificação de traços comuns no trabalho de historiadores espanhóis, portugueses, ingleses e assim por diante. ${ }^{4}$

1 Cf. LE GOFF, Jacques. Antigo/Moderno. In: ROMANO, Ruggiero. (Org.). Memória-História. Lisboa: Imprensa Nacional-Casa da Moeda, 1984; e BURKE, Peter. História e Sociologia. Porto: Afrontamento, 1985.

2 Cf. GIDDENS, Anthony. J ürgen Habermas. In: SKINNER, Quentin. (Org.). The Return of Grand Theory in the Human Sciences. Cambridge: Cambridge University Press, 1985.

3 Cf. WHITE, Hayden. Trópicos do discurso. São Paulo: Edusp, 2001, p.54.

4 Cf. GLÉNISSON, J ean. Iniciação aos estudos históricos. São Paulo: Difel, 1986, p.7. 


\section{0 fardo aristotélico}

Durante a Idade Média, a História não tinha sido matéria de ensino. A História era muito mais um aspecto de cultura geral do que de escola, afirmou Huizinga. "O sistema escolar da Idade Média", escreveu, "formado pela influência da tradição da Baixa Antigüidade, não reservava um lugar especial para a História". ${ }^{5} \mathrm{~A}$ influência restritiva de Aristóteles, o mestre incontestável dos homens de cultura daquela época, descredenciou-a do mundo dos saberes reconhecidos. Aristóteles, considera François Hartog, nada escreveu no gênero História. Contudo, suas reflexões na Poética, obra na qual estabelece a superioridade da poesia trágica (que diz respeito ao geral) sobre a narrativa histórica (limitada ao particular), estabeleceram 0 fardo que a historiografia carregou por muitos séculos. ${ }^{6}$

Entre os gregos antigos predominou a idéia de que a História deveria ser a narrativa encarregada da imortalização dos sucessos passados. Antes de Tucídides, a História não estabelecera relações muito definidas entre 0 presente e o passado, ou seja, ainda não se avaliava o passado como uma possibilidade de compreensão do presente. Segundo as necessidades do tempo, a História se prestava a um grande papel, sem dúvida, celebrando as façanhas dos grandes homens, recordando os seus feitos extraordinários de bravura, para fixá-los na memória dos homens, de uma maneira educativa e edificadora das virtudes. Esse foi o padrão predominante no horizonte cultural da época, do qual é muito esclarecedor o episódio de Leônidas, o rei de Esparta, com os seus Trezentos bravos no desfiladeiro das Termópilas. De fato, qual sentido poderia haver na escolha aparentemente enlouquecida de um bando de guerreiros sitiados que, em vez da rendição, escolheram partir para o confronto direto com um exército de milhões de soldados. Ao recusar a proposta de Xerxes, Leônidas tinha plena consciência da morte mais do que certa. Mas isso era o de menos. Diante de um fim próximo e incontornável, o importante e urgente era despachar um emissário para Esparta, levando a notícia daquela heróica resistência, para que não caísse no esquecimento. Essa é uma atitude cuja matriz já pode ser encontrada nos textos de Homero, notadamente em episódios da Odisséia, quando da passagem de Ulisses pelo reino dos feácios. Assim sendo, na Grécia antiga a História se ocupava em "extrair" do passado alguma lição moral isolada, particularizada, culpo que levou Aristóteles a torcer o nariz para este campo do saber.

5 HUIZINGA, J ohan. El concepto de Historia. México: FCE, 1994, p.37.

6 HARTOG, François. A História: de Homero a Santo Agostinho. Belo Horizonte: Editora UFMG, 2001, p.14. Para um historiador inglês, o problema apontado por Aristóteles está na não-inteligibilidade de um conjunto de acontecimentos reais dos quais não se pode extrair nenhuma regra universalizante. Cf. COLLINGWOOD, Robin. A idéia de História. Lisboa: Presença, 1981, p.36. 
Seguindo a falácia da autoridade das teorias aristotélicas, as Universidades medievais não a reconheceram em seus programas de ensino. Mesmo na época do Renascimento e, inclusive depois, a História desempenhou papel bastante secundário no elenco das disciplinas universitárias. A primeira cátedra de que se tem notícia foi criada em Mayence, Alemanha, no ano de 1504. Depois disso, outras cadeiras de História foram também criadas na Europa. Mas sempre como iniciativas isoladas, até os finais do século XVIII. Entre os homens que brilharam como historiadores nos séculos que se estendem do humanismo até o romantismo figuraram muito poucos formados nas escolas, reitera Huizinga. ${ }^{7}$ Isso significa que a História não possuía um lugar definido nos processos educativos formais e que, portanto, não havia professores de História. ${ }^{8}$ Como afirmou Pierre Chaunu, a necessidade de leitura da História surgiu apenas entre o final do século XVI e o princípio do século XVII como um fato de cultura totalmente autônomo da instituição escolar, mas um fato espontâneo, tão poderoso como uma onda. Para Chaunu, a Idade Média viveu muito intensamente a história para que pudesse falar dela. Passado e presente formavam uma só dimensão, em meio a um imaginário social e político dominado pelos prodígios divinos. ${ }^{9}$

A solidariedade entre o outrora e o agora, escreveu Marc Bloch, concebida com excessiva convicção, encobria as diferenças e anulava até mesmo qualquer necessidade de distingui-los. ${ }^{10} \mathrm{~A}$ essa operação intelectual J acques Le Goff denominou por "atualização" do passado, mormente dos grandes exemplos da Antigüidade bíblica. "O homem da Idade Média", considera Le Goff, "vive num constante anacronismo, ignora a cor, reveste os personagens da Antigüidade de hábitos, sentimentos e comportamentos medievais. Os cruzados acreditavam que iam a J erusalém vingar os verdad eiros carrascos de Cristo". ${ }^{11}$ Com os cronistas da Baixa Idade Média essa "nostalgia" vai apagar-se progressivamente, pelo reconhecimento das especificidades dos tempos históricos, no sentido atribuído por Reinhart Koselleck. ${ }^{12} \mathrm{~A}$ percepção da dinâmica dos "tempos históricos" muito tem a ver com a ruptura do ideal de Cristandade, a partir da ascensão das monar-

7 HUIZINGA, J ohan. El concepto de Historia, p.37.

8 Segundo um historiador italiano, essa era também a situação na Antigüidade greco-romana. Cf. MOMIGLIANO, Arnaldo. Ensayos de historiografia antigua y modema. México: FCE, 1993, p.152. Na avaliação de outro historiador, na Grécia antiga a História era um gênero literário lido nas escolas de retórica, nas avaliações de estilo. Mas a História nunca foi uma disciplina, nem uma profissão. Cf. HARTOG, François. A História: de Homero a Santo Agostinho, p.18s. Acerca do tema, veja-se ainda a opinião de COLLINGWOOD, Robin. A idéia de História, p.39.

9 Cf. CHAUNU, Pierre. A História como ciência social. Rio de J aneiro: Zahar, 1976.

10 Cf. BLOCH, Marc. La société féodale. Paris: Albin Michel, 1968.

11 LE GOFF, J acques. Passado/Presente. In: ROMANO, Ruggiero. (Org.). Memória-História, p.303.

12 Cf. KOSELLECK, Reinhart. Le futur passé. Contribution à la sémantique des temps historiques. Paris: EHESS, 1990. 
quias feudais e de suas demais fases evolutivas nas formas dos Estados principescos e Estados régios nos inícios da Época Moderna. ${ }^{13}$

\section{Uma questão de estilo}

Ao longo do Antigo Regime, os livros de História eram cópias uns dos outros, com uma tendência sem restrições para o decalque, para a simples glosa ou para exercícios bastante livres de redação de textos. História feita de rapinas e fervores, ou seja, de plágio e veneração dos modelos consagrados, no dizer de Charles-Olivier Carbonell. ${ }^{14} \mathrm{~A}$ criatividade dos autores manifestava-se apenas na arte de copiar, porque não importava produzir novas formas de interpretação dos acontecimentos. Esse é o "método de cola e tesoura", a técnica que Collingwood atribuiu aos historiadores da época helenística que, pretendendo escrever História sobre um passado mais afastado dos acontecimentos de seu próprio tempo, faziam-no recortando informações dos livros de Heródoto, Tucídides e de outros. Devido à incapacidade ou inaptidão para o estabelecimento de um juízo crítico norteador da pesquisa histórica, valia o peso do argumento da autoridade escolhida para legitimar tais e tais sucessos. A falácia da autoridade era a regra, porque era com as autoridades que os escritores se mediam, era por meio delas que venciam as discussões, ao sacar esse ou aquele argumento aparentemente irretorquível sobre a matéria em questão.

Até o século XVI a imitação fora uma técnica largamente utilizada pelo ensino humanista. A imitação não era apenas reconhecida como um exercício intelectual, mas como uma arte. Nesse sentido, emulavam-se as autoridades clássicas modelares, vultos da estatura de Cícero, de Sêneca, de Virgílio. Bom exemplo desse método pelo qual se ensinava as habilidades da escrita é oferecido pelo historiador Quentin Skinner, ao informar-nos do relato de um pai orgulhoso acerca dos progressos de um jovem destinado a uma fama extraordinária na república das letras. Em seu Diário, no dia 15 de novembro de 1481 Bernardo anotava que, naquela altura dos acontecimentos, o filho Nicolau - então com onze anos - , já estava escrevendo as suas próprias composições em latim, por meio da imitação dos clássicos. ${ }^{15}$ Anos mais tarde, a partir de sua participação no grupo dos Orti Oricellari, que se reunia nas proximidades de Florença, Maquiavel demonstrou a que grau de virtuosismo podia-se alcançar com a imitação dos antigos. Seus gorjeios literários na casa de Cosimo Rucellai valeram-lhe a produção de seu maior livro de política, os Discorsi, uma glosa que brotou de sua leitura

13 Acerca desta tipologia consulte-se BOBBIT, Phillip. A guerra e a paz na história moderna. Rio de J aneiro: Campus, 2003.

14 Cf. CARBONELL, Charles-Olivier. Historiografia. Lisboa: Teorema, 1987

15 Cf. SKINNER, Quentin. Maquiavel. São Paulo: Brasiliense, 1988, p.17. 
da obra histórica de Tito Lívio. Em jogo, nos textos históricos e políticos de Maquiavel, estava a preocupação em alcançar alguns efeitos especiais muito apreciados. Autoridades insuspeitadas da Antigüidade romana haviam estabelecido os princípios que deveriam reger a narrativa da História. Assim, “... para transmitir as lições mais salutares de forma mais memorável, o historiador deveria cultivar um poderoso estilo retórico. Como declarara Salústio no início de A Guerra com Catilina, o desafio particular da História reside no fato de que 'o estilo e a enunciação devem igualar-se aos feitos registrados'". ${ }^{16}$ Tais lições eram levadas a sério. Antes de dar início à História de Florença, Maquiavel compôs um ensaio de estilo no qual testava a aplicação desses princípios: a biografia de Castruccio Catracani. Contudo, nada nos textos do polígrafo Maquiavel autoriza afirmar que o referido "poderoso estilo retórico" - regra de ouro dos humanistas, e mais ainda dos escritores franceses do século XVII - , descambe para os adereços e a empolação. Pelo contrário, os diferentes tradutores de sua obra dão largas mostras de que seu estilo de escrita é sóbrio e direto, e que ele se ocupou muito mais em alcançar a essência das coisas, descartando os ornamentos. Para perceber isso, basta ler os "Escritos Políticos" e a obra epistolar, na qual se destaca a "Carta a Francesco Vettori", aquela famosa narrativa datada de 10 de dezembro de 1513, na qual se descreve as cenas desventuradas do "camponês humanista" nos tempos em que viveu fora de seu ambiente natural. ${ }^{17}$

Na França, o longo do século seguinte, a antiga técnica da imitação parece ter chegado em padrão já bem corrompido aos domínios da escrita da História. Daí os vôos de retórica de que tanto se queixou Montaigne. Como escreveu Paul Hazard em seu Crise da Consciência Européia, todos os historiadores charlatães do século XVII queriam igualar a glória de Tito Lívio e, para fazer espírito, elaboravam longos e maçantes discursos, atribuindo as mais finas sentenças aos homens mais ignorantes. ${ }^{18} \mathrm{Na}$ época dos Mézeray, Varillas, Vertot, Daniel, Saint-Réal, Eachard, Boyer, Burnet, De Sólis, o passado era concebido como matéria possuidora de um sentido fixo, como um objeto que deveria ficar fora de controvérsias. Segundo a percepção dos escritores Seiscentistas de livros de História, o passado estava "imobilizado", ${ }^{19}$ o que equivale a dizer que a história já fora narrada de forma suficiente pelos grandes nomes, valendo apenas o juízo de autoridade dos vultos célebres da tradição. Cabia recontá-la, sim, por meio de

16 SKINNER, Quentin. Maquiavel, p.122.

17 Cf. MAQUIAVEL. O Príncipe e Escritos Políticos. In: Os pensadores. São Paulo: Abril Cultural, 1973.

18 Cf. HAZARD, Paul. Crise da consciência européia. Lisboa: Cosmos, 1974.

19 Os episódios ocorridos no passado são imodificáveis, certamente, mas não as versões que acerca de tais episódios se produzem. A crença dos historiadores do tempo era a de que tudo já havia sido dito. Apelando para a autoridade de um metodólogo de reconhecido mérito, "O passado é, por definição, um dado que nada mais modificará. Mas o conhecimento do passado é uma coisa em progresso, que incessantemente se transforma e aperfeiçoa". BLOCH, Marc. Apologia da História. Rio de J aneiro: J orge Zahar, 2001, p.75. 
variações retóricas atualizadas. Cabia também edulcorá-la, para atender ao bom gosto das damas, buscando novas formas de composição dos textos, para aperfeiçoar e embelezar a narrativa, segundo o padrão estético da restrita comunidade de leitores da época. Ao que parece, nos domínios da História, nunca fora tão caudalosos os rios de retórica e o desperdício de tinta, a julgar pelas críticas de autores como Gusdorf, Ariès, Chaunu, Hazard, Fontana, Lefebvre. ${ }^{20}$

\section{Iguarias mal-digeridas}

Naqueles tempos, valiam mais os desfiles de hipérboles e as metáforas pomposas do que a análise dos acontecimentos passados. Veja-se 0 exemplo oferecido por Philippe Ariès em 0 Tempo da História. Segundo este historiador, a vida de Joana d'Arc é um episódio recorrente em todas as Histórias do século XVII. Mas o tema aparece sempre igual, sem variações de sentido ou divergências de interpretação. Apenas a forma de se contar a história da heroína é que ganha coloridos diversos, conforme a pena deste ou daquele historiador, que escreve "segundo o gosto dos tempos". Ainda estava distante o momento de se pensar no imperativo categórico proposto por Montesquieu em Do Espíito das Leis: "É preciso transportar-se para aqueles tempos", querendo dizer com isso que, ao historiador, seria necessário analisar os fatos com os valores próprios a cada cultura do passado. ${ }^{21}$ Segundo Montesquieu, os modelos equivocados de interpretação dos sucessos passados eram a fonte de toda sorte de vícios de uma obra. De fato, é procedente a crítica tecida pelo autor ao abade Dubos, que em vez de analisar os documentos históricos com "as luzes do tempo", ou seja, com a necessária isenção de espírito, tomava a interpretação de outros autores como a fonte inequívoca da verdade. Esse escritor melhor teria feito se tivesse limitado o seu ofício às Réflexions Critiques sur la Poésie et la Peinture do que se meter em projetos como os "três mortais volumes" de Établissement de la Monarchie Française, escreveu Montesquieu.

0 exibicionismo beletrista foi um traço característico dessas Histórias, num contexto intelectual em que a submissão ao modelo era lei no campo da reflexão e da escrita. Muito mais tarde, já na segunda metade do século XVIII, o historiador inglês Edward Gibbon observaria que a atitude de subserviência diante dos autores Antigos ajudou a retardar o avanço da cultura ocidental moderna. A autoridade inquestionável dos Antigos favoreceu apenas aos imitadores pedantes, que sobrecarregavam seus livros

20 Cf. GUSDORF, Georges. Introduction aux sciences humaines. Paris: CNRS, 1960; ARIĖS, Philippe. 0 tempo da História. Rio de J aneiro: Francisco Alves, 1989; CHAUNU, Pierre. A História como ciência social; HAZARD, Paul. Crise da consciência européia; FONTANA, J oseph. História: análise do passado e projeto social. Bauru: Edusc, 1998; LEFEBVRE, Georges. El nascimiento de la historiografía moderna. Barcelona: Martinez Roca, 1974.

21 Cf. MONTESQUIEU. Do Espírito das Leis. São Paulo: Abril Cultural, 1979. 
com numerosas máximas extraídas de seus modelos. Isso faz lembrar a crítica de Montaigne, que nos finais do século XVI já se queixava da escrita atapetada de citações, que fazia dos livros ventres estufados de iguarias mal-digeridas. E não que Montaigne fosse contra citações. Os Ensaios - bem como as tábuas que compõem o teto de sua torre-biblioteca, situada no castelo de sua família no sudoeste da França - estão recheados de máximas coladas de numerosos autores, principalmente Antigos, como Horácio, J uvenal, Cícero, Virgílio e Plutarco. Empregando metáforas naturais comuns em seu tempo, Montaigne lembra que os escritores precisariam ag ir como as abelhas. ${ }^{22}$

Com efeito, as abelhas pilham livremente na natureza tudo o que necessitam. Mas transformam suas pilhagens em mel, produto exclusivo de sua criação. A mensagem de Montaigne: o autor precisa utilizar a tradição literária para a criação de sua própria obra, lançando mão de autores e livros apenas para a elaboração de seu próprio pensamento. ${ }^{23}$ Opinião semelhante foi desenvolvida pelo filósofo Schopenhauer, aqui referido como alusão comparativa da produção literária em diferentes tempos. Ao tecer dura crítica aos "batalhões de asnos" que empestavam a literatura do século XIX, o filósofo alemão não se conformava com a escassez das idéias, com a pobreza do estilo, e com a aridez empertigada dos modismos efêmeros predominante em seu tempo, conforme se pode ler na sua muito conhecida coletânea de ensaios Parerga e Paralipomena, de 1851. "Tratase de conceitos emprestados", escreveu, "de toda uma tralha reunida, material gasto e surrado, como a reprodução de uma reprodução. E seu estilo, constituído por frases banais e palavras correntes da moda, é como um pequeno Estado cuja circulação monetária consiste apenas de moedas estrangeiras, porque não cunha a sua própria". ${ }^{24}$

Isso para lembrar que, no século XVII, escrever História era muito mais um processo literário de imitação e de obediência a cânones. Não havia esforço algum em inovar ou marcar qualquer tipo de diferença ou traço de originalidade já que se dispunha de modelos consagrados. Buscava-se acertar no grau máximo de eloqüência, em vez de acrescentar o maior rig or possível às pesquisas. Acerca do fato de se escrever história apenas sobre o que já havia sido dito por outros livros, Georges Gusdorf observou que, naquele tempo, a História era um gênero literário essencialmente fundado sobre a transmissão de uma narrativa fixada de uma vez portodas; ela se contentava por completar-se, de geração em geração, por meio da narrativa

22 Ao que parece, essa metáfora montaigniana teve como fonte de inspiração uma lição de Sêneca a Lucílio. Em sua carta Sêneca escreveu: "Devemos imitar as abelhas, pondo de lado o que colhemos durante as nossas diversas leituras, pois o que é separado se conserva melhor. (...). Os alimentos que absorvemos nos pesam, enquanto guardam a sua forma original e ficam inteiros no estômago; mas quando eles se transformam, passam para 0 sangue e nos dão forças". SÊNECA. As relações humanas. São Paulo: Editora Landy, 2002, p.73.

23 Cf. MONTAIGNE. Ensaios. São Paulo: Abril Cultural, 1972.

24 SCHOPENHAUER, Arthur. A arte de escrever. Porto Alegre: L\&PM, 2007, p.49. 
dos eventos recentes, e por alguns novos preciosismos de retórica. Foi assim que se constituiu uma História tradicional, que teve vida singularmente longa, porque o desenvolvimento da História científica não a destruiria. ${ }^{25}$ Mesmo assim, não deixa de ser surpreendente a "fórmula" encontrada pelo padre Buffier para ensinar a história de uma maneira eficaz, como conta Montesquieu: bastava escrevê-la em pequenos versos, fáceis de decorar. Ao historiador não caberia qualquer esforço para apresentar uma outra interpretação de episódios já conhecidos de todos; bastava apenas recontar, de forma agradável, o que os seus predecessores haviam notado. Esse padrão de subserviência aos autores-modelo persistiu até o Século das Luzes. Em resumo, prevalecia a concepção de que "o cerco já estava feito". Aliás, essa é a anedota mais famosa sobre o divórcio entre a erudição e a História. Conta-se que, nos finais do século XVII, o abade Vertot concluíra um relato da guerra dos turcos nas ilhas do Mediterrâneo. Georges Lefebvre escreve que, após ter escrito seu texto, Ihe apresentaram alguns novos documentos pertinentes ao seu tema. Ele teria respondido: "Minha história já está concluída". ${ }^{26} \mathrm{Em} J$ acques Le Goff encontramos a mesma anedota, em termos um pouco distintos. Tendo acabado sua obra sobre 0 cerco de Rodes pelos turcos, e sendo-lhe apresentado novos testemunhos, recusou-os com uma imprecação digna de um marechal à l'ancien régime: "O meu cerco já está feito". ${ }^{27}$

Ao triunfo da História Sagrada de Bossuet, e ao retorno do elenco de mitos políticos da velha França, na época de ascensão do Estado absolutista, seguiu-se um período de decadência do pensamento histórico, uma vez que o método de análise histórica esboçado pelos humanistas franceses da segunda metade do século XVI não teve herdeiros que o adotassem no século XVII; herdeiros que fossem capazes de conservar e aperfeiçoar seus critérios e exigências metodológicas e que, a exemplo dos Bodin, dos Hotman, dos La Popelinière, também fossem capazes de fazer do emprego de documentação original e de métodos de análise o sustentáculo do rigor da pesquisa, em termos de uma tentativa consciente de maior aproximação da veracidade dos acontecimentos. Isso porque, no século XVII, não teve seqüência o esforço de definição dos procedimentos técnicos de crítica documental que permitiriam falar em Historiografia propriamente dita. 0 que havia à época era uma série de esquemas narrativos, sempre pautados pelos grandes reis e seus reinados. Esse retrocesso da História coincidiu com um longo período de turbulências políticas e sociais que abalaram um Estado monárquico de relevo como a França, no decorrer de quase metade do século XVII: o assassinato de um rei, as revoltas camponesas, 
as turbulências da Fronda, a Guerra dos Trinta Anos, etc. Dessa forma, o empobrecimento metodológico nas obras de História sofreu a influência de tais crises, e cada autor, à maneira das velhas crônicas encomiásticas de reis e dinastias concebidas durante a Idade Média, prestou o seu contributo para a restauração da paz e da salvação do reino. Com efeito, o século XVII, que marca o apogeu do absolutismo, representou, segundo a análise de Pierre Chaunu, um "parêntese" no processo de desenvolvimento da História.

Mas nem tudo foi estagnação e atraso no campo dos estudos históricos. No século XVII, ordens religiosas como os Beneditinos e a Companhia de J esus concederam à História espaço considerável em seus colégios. Além do ensino, tais ordens se incumbiram de afinar os instrumentais da crítica documental. Algum tempo mais tarde, já nos meados do século XVIII, houve um movimento europeu para a escrita de uma História que não mais se restringiria à abordagem de temas políticos e acontecimentos militares, como fora até então. Com autores como Gibbon, Montesquieu, Hume, a tendência foi pensar nas leis gerais do desenvolvimento humano, nas relações comerciais entre os Estados, na relatividade dos usos e costumes dos povos. Essas coordenadas inovadoras da reflexão filosófica levaram à organização de um "questionário" mais complexo para a História, que foi reinventada segundo as novas exigências secularizantes do século de Voltaire. Ainda assim, os livros de História se destacavam pelas singularidades de cada autor, pelo brilho dos talentos individuais, pela sofisticação do estilo deste ou daquele escritor. E não que essas inovações tenham suprimido as velhas formas de escrita da História. Autores como Mézeray e o padre Daniel ainda gozaram, por longo tempo, de considerável prestígio sendo, inclusive, mais divulgados que os autores emergentes.

Não obstante os esforços anteriores, foi apenas nos inícios do XIX que professores de algumas Universidades européias, notadamente na Alemanha ${ }^{28}$ e na França, deixaram de reconhecer na História uma mera disciplina destinada a dar exemplos de ações aos grandes homens, ou a servir para a interpretação das leis gerais do progresso humano. A partir de então, a História foi transformada em um campo disciplinar autônomo, numa matéria de domínio quase exclusivo de profissionais especializados, que punham em prática técnicas de pesquisa reconhecidas por seus pares.

Assim é que, a rigor, o que se reconhece por vezes como Historiografia, até os finais do século XVIII era uma Babel de opiniões que, se possuía objetos históricos em comum, nada tinha que unificasse as formas de abordagem sobre tais objetos. Ao que parece, soa mesmo anacrônico

28 “... Alemanha é, sem concorrência, o país que produziu no século XIX o maior número de historiadores relevantes, todos eles saídos das escolas universitárias". HUIZINGA, J ohan. El concepto de Historia, p.37. Acerca da contribuição das Universidades alemãs para o advento da historiografia contemporânea leia-se as considerações de GLÉNISSON, J ean. Iniciação aos estudos históricos. 
falar em História da Historiografia para séculos anteriores ao XIX, o que não é verdade quando se fala em historiadores da Idade Média, do Renascimento, dos séculos XVII e XVIII. Esses historiadores eram "intelectuais" ou, como preferem alguns autores atuais - atendo-se ao anacronismo da expressão, por se tratar de um neologismo dos finais do século XIX - , homens de letras das mais diversas formações: clérigos, juristas, bibliotecários, filósofos, embaixadores e, até mesmo, historiógrafos, ou seja, os historiadores oficiais encarregados de escrever a história das cidades, das linhagens aristocráticas e das casas reinantes. Figuras como Maquiavel, à época dos Médici, e Voltaire, no reinado de Luís $\mathrm{XV}$, desempenharam esse ofício. Então, como falar com propriedade em Historiografia para épocas nas quais houve concepções de História segundo as idiossincrasias de cada historiador?

\section{"Enciclopédias do fantástico"}

Dito isso, pode-se falar com um pouco mais de propriedade em antigos gêneros de História. Segundo o historiador inglês Robin Collingwood, a tradição do pensamento histórico ocidental se constituiu à luz da tripla corrente que fez germinar a cultura histórica no Ocidente medieval e moderno: a cultura clássica, a germânica dos reinos bárbaros e o "fermento do cristianismo". ${ }^{29}$ Desse modo, distinguem-se três momentos mais nítidos nessa escalada que, pausada e progressivamente, foi se desenvolvendo em direção à perda da transcendência e a um maior apelo à documentação na interpretação do passado. Tal movimento marca a lenta passagem da narrativa à crítica, à investigação rigorosa fundada na pesquisa de fontes autênticas. Entretanto, esses três momentos - Alta Idade Média (séculos IV/X), Baixa Idade Média (séculos XI/XV) e Época Moderna (séculos XVI/ XVIII) - não podem ser retratados de forma esquemática. Em cada uma dessas épocas conviveram gêneros diversos de História que, normalmente, correspondiam a necessidades estritamente vinculadas a segmentos sociais que dominavam as técnicas da cultura erudita e que estavam mais próximos do poder político.

Ao Império Romano do Ocidente sucederam-se os reinos bárbaros na Europa. Na época dos reinos bárbaros, a cultura letrada conheceu um declínio em todas as áreas. Mas o gênero História não foi abandonado. Há obras de baixa relevância como texto, mas de alto valor como documento histórico, reveladoras do pensamento da época, um tempo marcado por controvérsias doutrinais de cunho político-teológico num período de afirmação do cristianismo. A arte de escrever História era diversificada; cada

29 Cf. COLLINGWOOD, Robin. A idéia de História. 
cabeça era um guia criativo e original. A única unidade no ofício talvez se devesse à posição social do "historiador", isto é, a sua condição de integrante de uma elite clerical. Essa posição social do narrador de fatos históricos fez da História uma narrativa de natureza teológico-religiosa. $\mathrm{Na}$ Baixa Idade Média, um livro de História era quase sempre uma abordagem de problemas doutrinais misturados a questões de fé, que evocavam a ação divina sobre a vida dos homens. Tratou-se de uma tradição literária que tinha um patrono atuante, a Igreja, razão pela qual a História era narrada segundo a perspectiva clerical.

Os gêneros predominantes no período foram quatro. Em primeiro plano estava a História politico-militar geral. Essas eram histórias pré-monarquias feudais, escritas por eclesiásticos nos reinos bárbaros, narrativas dos traços militares que caracterizavam os ostrogodos, visigodos, francos etc. Houve também a História de reis e imperadores, o que Carbonell denomina "biografia cortesã". ${ }^{30}$ Igualmente escrita por clérigos, tais narrativas decalcavam personagens extraídos do mundo greco-romano. Tratava-se de um tipo de narrativa anacrônica, em que Carlos Magno, por exemplo, era retratado como possuidor das virtudes de Augusto. Esse gênero era produzido por áulicos e panegiristas, contratados para cantar os mais exaltados louvores aos príncipes. J á as Cronografias universalizantes retratavam a história do mundo desde Adão até a época do autor. Os escritores do gênero estavam convencidos de que a história da humanidade só possuía sentido à luz dos Evangelhos. A História tornou-se um esforço de pura imaginação criativa sem qualquer apoio em documentos que não fossem as Sagradas Escrituras, lidas de uma certa maneira. Os principais autores no gênero foram Santo Agostinho e Eusébio de Cesaréia. As Vidas de Santos foram o gênero mais difundido entre as formas do discurso histórico medieval. Voltava-se, como os demais gêneros, para a edificação moral dos homens, mas com apelo a exemplos individuais de peregrinas virtudes cristãs.

A escatologia é um fator proeminente nesses gêneros. A história da humanidade seria a realização do plano de Deus, segundo a lente dos santos e dos monges: "O tempo, como os gregos o concebiam, era cíclico, repetitivo, privado de evolução sem retorno. Com A cidade de Deus, ele passa a ser uma reta orientada, traçada inteiramente entre uma origem e um fim. A história adquire então um sentido, na dupla acepção do termo: uma significação, uma direção". ${ }^{11}$ Durante a Idade Média, a História era assunto para teólogos, moralistas e clérigos. Ela não fazia parte de uma

30 Cf. CARBONELL, Charles-Olivier. Historiografia.

31 DROIT, Roger-Pol. A companhia dos filósofos. São Paulo: Martins Fontes, 2002, p.92. Segundo a interpretação de Mircea Eliade, “... o sentido dessa história é único, porque a Encarnação é um fato único. (...) 0 desenrolar da história é então comandado e orientado por um facto único, radicalmente singular". ELIADE, Mircea. 0 mito do eterno retomo. Lisboa: Edições 70, 1993, p.155. Le Goff expressa a mesma opinião. Cf. LE GOFF, J acques. Idades Míticas. In: ROMANO, Ruggiero. (Org.). Memória-História, p.322. 
cultura leiga. Um balanço do período poderia ser assim descrito: os gêneros anteriormente definidos eram indiferentes à historicidade dos eventos que narravam. Tudo era igual a tudo nesses antigos textos medievais; não havia a menor idéia de diferença dos valores culturais das sociedades no tempo. Os diversos gêneros de História eram "enciclopédias do fantástico" - como dizia Voltaire das histórias lendárias - sem a preocupação de distinguir as especificidades dos tempos históricos. E seria mesmo anacrônico cobrar essa preocupação dos homens de letras da Idade Média, porque o passado era vivido como presente. Aliás, como demonstrou Ariès, essa noção predominou até os meados do século XVII. Foi quando se passou a estabelecer a distinção entre os sucessos passados e os acontecimentos presentes. Nos livros de História, diz Áries, a noção de diferença dos tempos históricos se deu após a morte de Henrique IV, ou seja, a partir das décadas subseqüentes a 1610. A morte trágica do rei foi percebida como um divisor de águas, 0 advento de um novo tempo. ${ }^{32}$

Situando-se o desenvolvimento do pensamento histórico medieval em seu contexto de produção, nota-se o movimento das Cruzadas como 0 responsável por uma relativa humanização da História. 0 guerreiro cristão foi alçado à dignidade de objeto da narrativa, em meio a seus esforços para realizar a obra de Deus. Para trilhar com segurança o percurso das monarquias feudais em processo de se constituírem como as estruturas políticas que representariam o futuro da Europa, em detrimento do ideal de Cristandade, foi preciso "construir" o passado dessas monarquias, forjando a sua memória coletiva como o núcleo condutor de uma comunidade de destino. Na Baixa Idade Média, o processo de reconhecimento do poder régio levou à criação de representações sobre a legitimidade das monarquias feudais, nas lutas políticas que travavam entre si e nos enfrentamentos diante das pretensões políticas da Igreja e do Império.

Foi em meio ao processo de constituição do poder régio que o historiador alcançou um status privilegiado. Ele atuou como o construtor da memória, o arquiteto da linhagem real e de seu reino, fabricando e divulgando suas origens gloriosas, bem como os traços caracterizadores de uma identidade comum. Essa foi a época em que a leitura de textos de História passou a atingir uma parcela mais ampla de leitores. Nos fins da Idade Média, a escrita da História rompeu o círculo dos ambientes clericais (mosteiros, abadias, etc.), para tornar-se um gênero literário de prestígio, concorrente direto das canções de gesta e dos romances de cavalaria. São dessa época as chamadas crônicas do tempo presente, do tempo vivido e narrado pelo historiador-cronista. No gênero destacaram-se autores como J oinville (narrativas da Sétima Cruzada) e Froissart (narrativas da Guerra dos

32 Cf. ARIÈS, Philippe. O tempo da História. 
Cem Anos). A modernidade das crônicas medievais está no aparecimento, ainda residual, das primeiras exaltações de um espírito proto-nacional. Tais crônicas eram histórias da corte e de batalhas, narrativas dessacralizadas dos acontecimentos militares - mas não inteiramente laicas - , realistas e meio nacionais, prenúncios da Renascença.

Sem dúvida, a História teve diversas atribuições em fins da Idade Média, e uma delas foi a de ser o instrumento de combate ideológico dos poderes nacionais emergentes, pela conquista de uma consciência nacional e de um sentimento de identidade, consubstanciados na idéia de um passado vivido em comum. Ligada às monarquias desde os finais da Idade Média, a História selou a sentença de morte do ideal de Cristandade, representado pela Igreja e pelo Império. Ela ajudou a forjar a Modernidade, marcada pelo realce dos particularismos políticos. Com o passar dos séculos, verificou-se uma diversificação dos gêneros de História. A partir do século XV, torna-se mais difícil defini-los. Surgiram novas tendências de como escrever História, o que não significa que os gêneros do passado tenham sido completamente extintos. Verificou-se, inclusive, uma maior complexidade no plano intelectual. Mas, o certo é que tais gêneros de História evoluíram acompanhando o desenvolvimento cultural das sociedades européias. Desse modo, a nova História dos humanistas dos séculos XV e XVI conviveu com as antigas concepções medievais de História Sagrada. Mas, a idéia do tempo histórico foi sensivelmente alterada. Para alguns autores - Maquiavel, por exemplo - o tempo deixou de ser uma linha reta na qual se aguardava o drama da salvação, para retornar ao antigo tempo cíclico das realizações humanas, tempo esse marcado por apogeus e declínios.

\section{A exemplaridade do passado e a imitação dos antigos}

A nova História humanista do século XVI rompeu com a concepção providencialista da História, que deixou de ser História do mundo e História Sagrada. Com os humanistas do Renascimento, sobretudo os eruditos franceses da segunda metade do século XVI, ocorreu a fragmentação do campo temático da História e, em vez das Cronografias ou Histórias muito amplas, passou-se a escrever a História do reino, do ducado, da cidade, da região, do indivíduo (biografias). No tempo de Bodin, Hotman, La Popelinière, passou-se também a incorporar reflexões sobre questões de método na análise dos documentos históricos, para apurar aspectos como originalidade e autenticidade das fontes. De quebra, agregaram-se noções de relatividade das culturas, com um respeito mais acentuado ao espírito do tempo das sociedades retratadas. Esse novo gênero de História

- não mais exaltação ou puro relato do passado, mas explicação inteligível - floresceu, sobretudo, na Itália do início do século XVI, mas também na França da segunda metade do mesmo século. Contudo, tais Histórias não 
foram além de um programa de intenções proposto por alguns eruditos isolados. Em síntese, no século XVI, esboçaram-se alguns pressupostos que se assemelhavam ao chamado método histórico do século XIX, ou seja, um conjunto de técnicas eruditas destinadas a apoiar o trabalho do historiador. No entanto, tais conquistas foram fragmentadas por diversas influências do mundo real, que não permitiram fazer avançar a História como um campo formal e independente do conhecimento sobre as sociedades. Como afirmado acima, tais avanços foram retomados apenas em fins do século XVII, por obra dos jesuítas e dos beneditinos, que por essa época terçaram armas teóricas com os eruditos protestantes, então na dianteira da exegese bíblica.

O humanismo da Renascença italiana, além de exercer a sua influência sobre as artes visuais, expandiu-se pelos diversos gêneros de literatura. Em Florença, a História passou de uma fase retórico-política para a de um discurso crítico que não pretendia apenas expor e narrar fatos, mas ordená-los de forma coerente e racional, buscando um sentido, uma lógica para os acontecimentos. Houve toda uma reflexão sobre os métodos a serem empregados pelo historiador-humanista. $\mathrm{Na}$ avaliação do historiador suíço Edouard Fueter, Francesco Guicciardini e Nicolau Maquiavel foram os maiores representantes dessa História. ${ }^{33}$ Esses pensadores podem ser considerados grandes precursores da chamada "História Perfeita" do século $\mathrm{XVI}$, voltada para a crítica das fontes, para a recusa dos mitos fundadores e, sobretudo, para a crença de que se poderia alcançar a verdade plena sobre o passado. Com Maquiavel e Guicciardini, o historiador deixava de ser um mero ensaísta - no sentido de que seu trabalho não possuía uma sólida base documental - , para passar a ser um profissional que lidava com fontes inéditas.

Acerca do Maquiavel historiador talvez caibam aqui algumas breves referências. Na "Carta a Zenóbio Buondelmonti e a Cosme Ruccelai", Maquiavel expressa sua gratidão a dois amigos de Florença. Ao oferecer seus Discorsi a Buondelmonti e Ruccelai o autor destaca a sua escolha em trilhar na contramão das convenções de seu tempo, fazendo o caminho inverso dos "... escritores que dedicam seus livros a algum príncipe...". Sem dúvida, sua atitude era inusitada e até mesmo paradoxal, sobretudo para quem já havia endereçado $O$ Prínc ipe como oferenda a um patrono como Lorenzo de Médici, logo após o término da experiência republicana em sua cidade.

Da frustração de uma acolhida fria ou indiferente por parte do novo príncipe talvez derive a sua decisão em dedicar os Discorsi a dois honrados cidadãos comuns, mas que certamente não se deixariam cegar pela "ambição e avareza". Por não ter alcançado as distinções e honrarias almejadas 
em sua primeira investida à cata de reconhecimento dos homens de poder, é compreensível que Maquiavel tenha se resignado a distinguir os dois amigos, a quem julgou mais merecedores da dedicatória de uma obra que ele mesmo avaliava como a melhor reflexão que até então produzira.

Acerca dessa questão, o episódio ocorrido com Maquiavel é ilustrativo porque a sua escolha não era, de modo algum, a regra adotada pelos homens de letras dos Tempos Modernos. Em uma época de afirmação de um poder que, em sua ascensão, passou a concentrar o monopólio da força - bem como o das distinções e honrarias tão febrilmente perseguidas - , também o discurso histórico passou a ter, na figura do primaz da política, o seu objeto central de reflexão. Com efeito, tanto 0 Príncipe como os Discorsi são livros de História, ainda que a reflexão política seja o traço predominante nas análises do historiador de Florença. Na Itália desde os finais da Idade Média e, inclusive, muito além destes tempos e em outras regiões da Europa, lembra o historiador Britânico J ohn Law, os historiadores tenderam para aquela posição um tanto suspeita de "amigos do rei": "Certas demonstrações de fidelidade e certas interpretações de todo o Estado, sob o ponto de vista do senhor, revelam uma tendência para exagerar a eficiência do governo central e para aceitar os seus objetivos". ${ }^{34}$

No tempo de Maquiavel, o estudo da história era dedicado - de forma predominante, mas não exclusiva - à percepção do sentido dos feitos memoráveis. Sendo assim, o conhecimento histórico possuía uma utilidade: prepararas ações necessárias ao presente, ou seja, fazer frente às urgências da atualidade como, por exemplo, os perigos enfrentados pelas invasões das potências estrangeiras. 0 espelho do comportamento recomendado aos homens do tempo presente do autor eram as atitudes exemplares dos antigos. Devia-se proceder, então, por imitação.

No plano intelectual, o próprio Maquiavel deu bom exemplo dessa tendência já que, em seus Discorsi, seguiu as passadas de Tito Lívio. Isso porque, naquele tempo, acreditava-se que também as criações intelectuais deviam ser imitadas dos modelos da Antiguidade e que, inclusive, tais criações podiam superar tais modelos, porum maior engenho que os modernos passaram a demonstrar. Aliás, "exemplo" e "imitação" são os termos mais recorrentes no discurso histórico de Maquiavel, além de se constituírem nas categorias analíticas fundamentais de seu método de estudo. Por isso, ele sempre recomendava aos cidadãos e aos príncipes que "aprendessem as lições da história". 35

No século XVI, durante um breve tempo, a História crítica se desenvolveu com os humanistas da Renascença. Eles se encarregaram de jogar por

34 LAW, J ohn. O príncipe do Renascimento. In: GARIN, Eugenio. (Org.). O homem do Renascimento. Lisboa: Editorial Presença, 1991, p.35.

35 MAQUIAVEL. Comentários sobre a Primeira Década de Tito Lívio. Brasília: Editora UnB, 1979, p.53 
terra uma série de mitos, como a "Doação de Constantino", ou a "origem troiana dos franceses". Buscaram na crítica filológica, e em outras fontes, os acontecimentos do passado, evitando explicações teológicas da história. Como se afirmou, Maquiavel e outros humanistas desenvolveram uma perspectiva de tempo cíclico, alternando na história períodos de luz e sombras, ignorância e esclarecimento, declínios e ascensões. Foi assim que a Idade Média se tornou, pela primeira vez, um abismo de trevas, precedendo uma época de conquista e avanços. Mas, isso foi apenas um foco de fissura num tempo ainda marcado pelas antigas concepções. No século XVII, com o triunfo do Estado absolutista, a História crítica dos humanistas regrediu. O gênero histórico que cresceu com ímpeto foi o dos "romances de reis", segundo a expressão de Ariès, com o elogio à monarquia de direito divino e ao seu núcleo sagrado: a realeza cristocêntrica. Para Kenneth Minogue, "Desde tempos imemoriais a política é na Europa um negócio de monarcas e seus servidores e a história tem sido em grande parte a narrativa de seus feitos". 36

Há de se considerar, ainda, a influência intelectual de Descartes, muito desfavorável à História. Para Descartes, sendo uma ciência do particular, a História não era capaz de explicar coisa alguma, daí ter passado a ser obra de panegiristas de cabeças coroadas. Foi o dito "parêntese cartesiano". E o triunfo do universal sobre o contingente alcançou com vigor a Época Moderna, tendo por arauto ninguém menos do que Descartes. Os historiadores de hoje 0 vêem como o detrator das credenciais cientificistas da história. Segundo Descartes, a História era uma forma de conhecimento tão limitada, que até mesmo uma simples escrava que tivesse vivido na Antiguidade, conheceria melhor a história do Império Romano que o maior dos historiadores do século XVII. As reflexões teórico-metodológicas de Leo Strauss expressam com propriedade esse argumento de Descartes. Strauss considerou que muitos historiadores atuais penetram menos do que as pessoas comuns do século XVII em seu sistema de representações. Isso se dá basicamente porque essas últimas possuíam uma clara consciência da natureza profunda do problema teológico e, inclusive, da peculiaridade de seus detalhes. ${ }^{37}$

\section{Idolatria régia}

O século XVII, época de esplendor do absolutismo, é sem dúvida um capítulo relevante na escalada da História-conhecimento. A dita Idade Clássica, cuja periodização tradicional circunscreve a Europa dos anos 1630-1760, não foi um bom tempo para o desenvolvimento da História.

36 MINOGUE, Kenneth. Política: uma brevíssima introdução. Rio de J aneiro: J orge Zahar, 1998, p.16.

37 Cf. STRAUSS, Leo. What is Political Philosophy? New York: Free Press, 1968. 
Como notou Georges Lefebvre, na França do século XVII a História retrocedeu, devido ao ímpeto da Contra-Reforma e aos efeitos nocivos de seus desdobramentos, como a diminuição de liberdade de criação e expressão literária, atividades muito desfavorecidas pela quase onipresença do Estado absolutista. ${ }^{38}$ Advém daí o retorno e o império absoluto do mítico e do lendário nas Histórias escritas no século XVII, em contraste com os avanços significativos do período anterior. Ao triunfo da História Sagrada, e ao retorno do rico elenco de mitos políticos da velha França, seguiu-se um período de decadência do pensamento histórico ocidental, uma vez que 0 "método" esboçado pelos humanistas italianos e franceses do século XVI não resistiu às novas exigências da monarquia absolutista. Esse retrocesso coincidiu com um longo período de turbulências políticas e sociais que sacudiram a França no curso de quase todo o século XVII. Dessa forma, o empobrecimento metodológico nas obras de História dessa época sofreu a influência de tais crises e os autores de livros de História, à maneira das velhas crônicas patrióticas da Idade Média, prestaram o seu tributo para 0 retorno da paz e da salvação pública do reino.

As crises de insegurança que fizeram do século XVII francês uma era de incertezas, com suas guerras civis e revoltas camponesas, levaram a História a se engajar na luta pela reconstrução do Estado monárquico, enfraquecido também pelas Guerras de Religião do século XVI. O texto de História desse tempo foi um discurso sobre a realeza, encarada como centro vital da sociedade política, e concebida como seu ponto de equilíbrio. A imagem do príncipe cristão, identificado com a monarquia, mais do que em qualquer outra época, constituiu o centro da narrativa histórica. ${ }^{39} \mathrm{Na}$ apresentação da Politique, de Bossuet, J acques Le Brun afirma que o século XVII francês assistiu ao desabrochar de uma autêntica "id olatria monárquica". ${ }^{40}$ Idolatria esta que, a exemplo de outros temas, como a discussão sobre a melhor forma de governo ou acerca das virtudes morais do soberano, migrou de autor para autor, numa verdadeira moda literária.

As Histórias da França produzidas no século XVII são sintomáticas dessa devoção quase sem limites à realeza sagrada. Em sua Histoire de France, um dos historiadores de maior expressão no século XVII, o padre Gabriel Daniel, refletiu muito claramente esta tendência de adesão irrestrita ao poder régio, ao observar que toda a história converge para a realeza, ou seja, em direção ao príncipe virtuoso. A História de um reino ou de uma

38 Cf. LEFEBVRE, Georges. El nascimiento de la historiografia moderna.; e HUPPERT, George. L' idée de l'histoire parfaite. Paris: Flammarion, 1973.

39 Como observa um historiador inglês, "A imagem recorrente do escritor que, de joelhos, oferece o seu livro ao príncipe (uma imagem que surge em muitos manuscritos do século XV) corresponde freqüentemente à realidade". BURKE, Peter. O cortesão. In: GARIN, Eugenio. (Org.). O homem do Renascimento, p.107. Tal afirmação é tanto mais pertinente para os séculos XVI e XVII.

40 Cf. LE BRUN, J acques. Introduction. In: BOSSUET, J acques-Bénigne. Politique tirée des propres paroles de l'Ecriture Sainte. Genève, Droz, 1967. 
nação tinha por objeto o Príncipe e o Estado. 0 príncipe cristão era o centro para onde tudo devia tender e se relacionar. Roger Chartier acrescenta que, de modo geral, as Histórias da França do século XVII correspondiam ao programa monárquico, mesmo que não tivessem sido encomendadas ou patrocinadas pelo Estado. Por isso, elas se conformavam às exigências do poder soberano. ${ }^{41}$ Dessa forma, a História produzida ao longo do século $\mathrm{XVII}$ - por historiógrafos a soldo régio e pelos demais homens de letras, muitos deles pensionistas da monarquia - , acabou por se transformarnum eficiente instrumento de propaganda do Estado monárquico. Esses escritores procuraram retratar a história dinástica sob o ângulo mais favorável, o que, além de garantir-Ihes a pensão, Ihes abria caminho para uma série de benesses: acesso privilegiado a fontes eclesiásticas, por exemplo..$^{42} \mathrm{E}$ isso foi possível porque a História já contava com seu público, ou seja, com um número representativo de interessados e assíduos leitores.

No verbete "História", do Dicionário Filosófico, essa História foi caracterizada por Voltaire como uma narrativa "desfigurada pela fábula", um discurso encomiástico da dinastia capetíngia ou do príncipe reinante em sua glória. Segundo a análise de Charles-Olivier Carbonell, o público exigia que a História fosse recreativa. Em conseqüência, deveria também ser romanesca. Não poderia ser erudita nem filosófica. Deveria ser apenas História literária, ao combinara inspiração cavaleiresca da Idade Média agonizante e da Renascença - proezas do herói, choque de paixões - com as receitas da retórica romana. Enfim, os autores deveriam dramatizar a narrativa, recheando-a com reflexões morais.

No âmbito das grandes tendências que demarcaram o desenvolvimento do Estado monárquico francês em aproximadamente três séculos de história, os autores de livros de História assumiram papéis importantes. A função de historiógrafo fora patrocinada, desde a França medieval, por reis e barões feudais. Na Idade Média, as casas senhoriais possuíam o seu historióg rafo oficial, cuja função era relatar feitos guerreiros e traçar árvores genealógicas de seus senhores, transformando-os em heróis dos campos de batalhas, ou mesmo aproximando-os em algum grau de parentesco a certo destacado personagem da mitologia greco-romana.

Nos séculos XVI e XVII, e ainda mais no XVIII, o Estado ampliou o número de pensões a esses profissionais. A glorificação do reino e do Príncipe reinante manteve-se como objeto central do discurso histórico. A realeza, que com a graça divina derrotava as forças desagregadoras e retomava a paz do reino, persistiu como tema privilegiado dos historiadores. 0 desejo de glória, maior anseio dos príncipes da era absolutista, favoreceu a atividade dessa História literária que se alimentava de mitos variados.

41 Cf. CHARTIER, Roger. Apresentação. In: ARIÈS, Philippe. 0 tempo da História.

42 Cf. BURKE, Peter. O cortesão. In: GARIN, Eugenio. (Org.). O homem do Renascimento, p.107. 
Numa época de afirmação dos Estados europeus, e do aparecimento dos primeiros indícios das identidades nacionais, a ostentação de poder e de prestígio impressionava tanto no interior do reino quanto fora dele. Num tempo marcado por guerras internacionais, disputas de fronteiras e anexações, em que a política externa passou a requerer, cada vez mais, homens intelectualmente capacitados, foi aos historiadores que o Estado recorreu. Foram eles os principais responsáveis pela cultura histórica e pela formação política dos príncipes e dos altos servidores da monarquia, ainda que não exclusivamente.

O Estado absolutista francês instalou-se no topo de uma complexa pirâmide de hierarquias sociais. Se em sua "política externa" não admitia nenhuma potência acima de si mesmo, no interior do reino sufocou qualquer discurso que fosse desfavorável à propaganda monárquica, que foi estendida até aos campos de batalha. A lei da mordaça imposta pelos príncipes absolutistas à História, que se tornou uma "arte", foi muito criticada por autores setecentistas. Montesquieu, por exemplo..$^{43}$ Inegavelmente, os modelos de História existentes no século XVII, entre os quais se encontram crônicas universais, histórias patrióticas, biografias e memórias, quase sempre foram discursos engagés, cujo tom predominantemente lealista e patriótico militou no sentido da afirmação de uma identidade nacional ancorada num passado mítico, que pretendeu fazer da coroa da França a primeira da cristandade. Esse esquema historiográfico levou inequivocamente ao recrutamento da História para o ofício de celebração do poder e da glória do Príncipe. Ao longo de séculos, o Estado monárquico administrou com competência a memória do reino, a ponto de fazer da História, na segunda metade do século XVII, um gênero literário dotado de uma finalidade prática. A historiadora da literatura Nicole Ferrier-Caverivière demonstrou como a figura dominadora de Luís XIV aprofundou essa relação de comando e subserviência dos homens de letras que se ocuparam da História a um nível inconcebível em qualquer Estado europeu da Época Moderna. ${ }^{44}$ Como afirmou o historiador holandês Huizinga, cada cultura cria e tem necessariamente de criar sua forma específica de escrita da História, determinando o que, para ela, é a História, e como deve ser escrita. Na França do século XVII essa História coincidiu com o reino..$^{45}$ Acerca desse assunto é instrutiva a análise de Louis Marin, ao refletir sobre 0 "Projet de l'Histoire de Louis XIV", de autoria do historiógrafo régio Pellisson, texto datado de 1670. 0 texto de Pelisson, expressão oficial da cultura histórica do tempo,

43 “... os príncipes fizeram dessa arte o principal objeto de sua polícia; os censores que estabeleceram dirigem todas as plumas". Cito aqui trechos de "Mes pensées", em excertos reunidos por STAROBINSKI, J ean. Montesquieu. São Paulo: Companhia das Letras, 1990, p.150.

44 Cf. FERRIER-CAVERIVIĖRE, Nicole. L'image de Louis XIV dans la littérature française de 1660 à 1715. Paris: PUF, 1981. Acerca da História na época de Luís XIV leia-se APOSTOLIDĖS, J ean-Marie. Le roi-machine. Paris: Editions Minuit, 1987, p.122ss.

45 Cf. HUIZINGA, J ohan. El concepto de Historia, p.93 
traçava as coordenadas para a escrita de uma nova História que era a mais escancarada louvação da realeza até então imaginada. Essa nova História deveria afirmar que todas as ações do rei eram milagrosas. A história do rei seria um assombro contínuo de feitos magníficos e os outros viventes que tiveram a sorte de ter vindo ao mundo não existiriam por seus próprios atos, palavras ou pensamentos, mas apenas para distinguir o milagre perpétuo das ações extraordinárias do príncipe. Assim, a História ofereceria o milagre dos acontecimentos exemplares, os gestos colossais do rei que produzem a história e, produzindo-a, daria sentido a toda a realidade. ${ }^{46}$ Tradução perfeita desses assomos de idolatria régia é citado por Marin, na pessoa do dramaturgo J ean Racine. Dizia Racine, em seu "Eloge historique", que "A história do rei (...) é uma seqüência contínua dos episódios magníficos que ele dá início e que ele finaliza. (...) Em uma palavra, o milagre segue de perto um outro milagre". ${ }^{47}$

Em qualquer um dos gêneros que existiu no Antigo Regime, a História não escapou do esquema das lições morais e das máximas políticas, até porque sua principal função, na época, era pedagógica: instruir os homens que conduziam a nação, porque as grandes causas se repetiam, e a esses homens cabia uma determinada previsão dos fatos. 0 prestígio da monarquia francesa, entre os demais Estados europeus, estava, dessa maneira, ligado à História. Concebida como Magistra vitae, compreende-se a vocação política da História e porque ela permaneceu por muito tempo ligada aos assuntos políticos, às versões das guerras e conquistas. ${ }^{48} \mathrm{E}$ isso desde os primeiros relatos faraônicos, até o século XIX. Na França, a História sempre foi marcada pelo mito régio que, enfraquecido em determinadas épocas, como no contexto das lutas religiosas do século XVI, ressurgiu triunfal das próprias cinzas. A temática do rei-deus, assunto recorrente no pensamento histórico de Bossuet, tornou-se lugar-comum na literatura francesa do século XVII. ${ }^{49}$

0 velho estilo literário medieval espelhos de príncipes, adaptado e aprimorado como catecismo régio ao longo do Antigo Regime, foi o "fio metodológico" condutor de inúmeras Histórias da França produzidas no século XVII. Ao lado das instruções morais ao príncipe virtuoso, para guiá-lo no caminho reto rumo à salvação pública, houve uma valorização da realeza como centro sagrado, como ponto de equilíbrio e princípio organizador da sociedade política. 0 Grand Siècle assistiu ao triunfo da pedagogia real na História, a um retorno e rejuvenescimento dos miroir des princes,

46 Cf. MARIN, Louis. Le portrait du roi. Paris: Editions Minuit, 1981, p.102.

47 Citado por MARIN, Louis. Le portrait du roi, p.101.

48 Cf. KOSELLECK, Reinhart. Le futur passé. Contribution à la sémantique des temps historiques; FONTANA, J oseph. História: análise do passado e projeto social; HADDOCK, B. Uma introdução ao pensamento histórico. Lisboa: Gradiva, 1989.

49 Cf. BOSSUET, J acques-Bénigne. Discours sur l'histoire Universelle e Politique tirée des propres paroles de l'Ecriture Sainte. 
juntamente com uma quase divinização da realeza. Para Georges Durand, essas perspectivas convergem basicamente porque tudo passou a depender do príncipe como único detentor da autoridade..$^{50} \mathrm{Com}$ efeito, ao longo do Ancien Régime produziu um conjunto interminável de textos políticos e históricos cujo núcleo temático era a monarquia, personalizada pela realeza sagrada. No Antigo Regime, a História tornara-se uma forma estratégica de discurso para o poder real. Assim sendo, os historiógrafos foram peças importantes nos jogos do poder, pois legitimavam ou desconstruíam tradições, segundo interesses pragmáticos, além de interferirem em questões cruciais do Estado monárquico. E assim continuaram a desempenhar o seu papel de construtores da memória do reino durante longo tempo. Dessa maneira, é compreensível que os livros de História estivessem sob a guarda atenta do príncipe. 